\title{
GEOGRAPHICAL PERSPECTIVE OF GENERAL LAND USE LAND COVER OF BAGALKOT DISTRICT: SPATIAL ANALYSIS
}

\section{DR. BASAVARAJ R. BAGADE}

Assistant Professor, Department of studies in Geography, Rani Channamma University, Belagavi, Karnataka, India \begin{abstract}
The use of GIS and remote sensing in mapping Land Use Land Cover in Bagalkot district is examined in this paper. The land use/land cover (LULC) pattern of a region across time and space is the result of natural and socioeconomic variables, as well as man's use of them after the building of the Upper Krishna Project in Bagalkot district. Land use is not a homogeneous process in Bagalkot District, Karnataka. Hence, land use manipulation by human beings is widespread and has become a serious threat to watershed services including streamflow regulation, soil erosion control, and low-flow augmentation at both micro-and macro-level catchments. The Understanding of Land Use through supervised and unsupervised classification of Land use by using RS and GIS technology helps in understanding the driving mechanism that causes land-use change. Therefore, an attempt will make to prepare LULC map of Bagalkot district, Karnataka by using Supervised and unsupervised classification. The classification will be developing through an unsupervised classification approach that will find prominent features of the area. However, analysis of supervised classification from multi-temporal satellite imageries estimated 16 land use/ land cover with respect to the rate of changes in the Bagalkot district. Bagalkot district is in the northern part of Karnataka state, situated in the interior of the Deccan Plateau or Bailusime region. It has the greatest extent of $101 \mathrm{kms}$ from north to south and $138 \mathrm{kms}$ from east to west. The most conspicuous of the very high and very low areas of the district is located at 500 and $600 \mathrm{mts}$ of contour lines above the main sea level. In terms of the area, Bagalkot occupies 15th place among the districts. Since this study is time-bound, the researcher has selected an area that is geographically small and easily manageable from the point of investigation and analysis. )
\end{abstract}

KEYWORDS: Geographical Perspective, Spatial Analysis, Bagalkot District \& General Land

Received: Jun 29, 2021; Accepted: Jul 19, 2021; Published: Jul 31, 2021; Paper Id.: IJCSEIERDDEC20214

\section{INTRODUCTION}

The land use/land cover (LULC) pattern of a region in time and space is an outcome of natural and socio-economic factors and their utilization by man. Study on Land use and land cover become a central component in current strategies for sustainable management of natural resources and monitoring environmental changes in the territory. The land use/land cover (LULC) the pattern of a region in time and space is an outcome of natural and socioeconomic factors and their utilization by man after construction Upper Krishna Project in Bagalkot district change in the land use land cover in Bagalkot District, Karnataka, Hence, land use manipulation by human beings is widespread and become a serious threat to watershed services including streamflow regulation, soil erosion control, and low-flow augmentation at both micro-and macro-level catchments. In the recent time, changes in land use and land cover has become one of the important components in monitoring watershed services especially hydrological services of the region. Further, change detection of vegetation patterns at the watershed level helps in enhancing the capacity of local governments to implement sound watershed management practices. New technologies like satellite 
Remote Sensing (RS) and Geographical Information Systems (GIS) provides a modern foray into the issues of resources management at a regional and national scale. Further, these advanced geospatial technologies have improved the efficiency of mapping of land use land cover types at the landscape level. The Understanding of Land Use through supervised and unsupervised classification of Land use by using RS and GIS technology help in understanding the driving mechanism that causes land-use change. In addition, they are valuable for a scientific base of the regional management, decision making and sustainable use of land and water (Fredrick et. al, 2013, LI Rui et. al., 2002). Thus, an integrated approach is essential and these combined techniques form a potential tool for land use land cover change detection analysis at both regional and local scales. Therefore, an attempt will make to prepare LULC map of Bagalkot district, Karnataka by using Supervised and unsupervised classification.

\section{OBJECTIVES OF THE STUDY}

- To prepare land use/ land cover map of Bagalkot district by using Remote Sensing and GIS applications

- To compare the results of supervised and unsupervised classification maps.

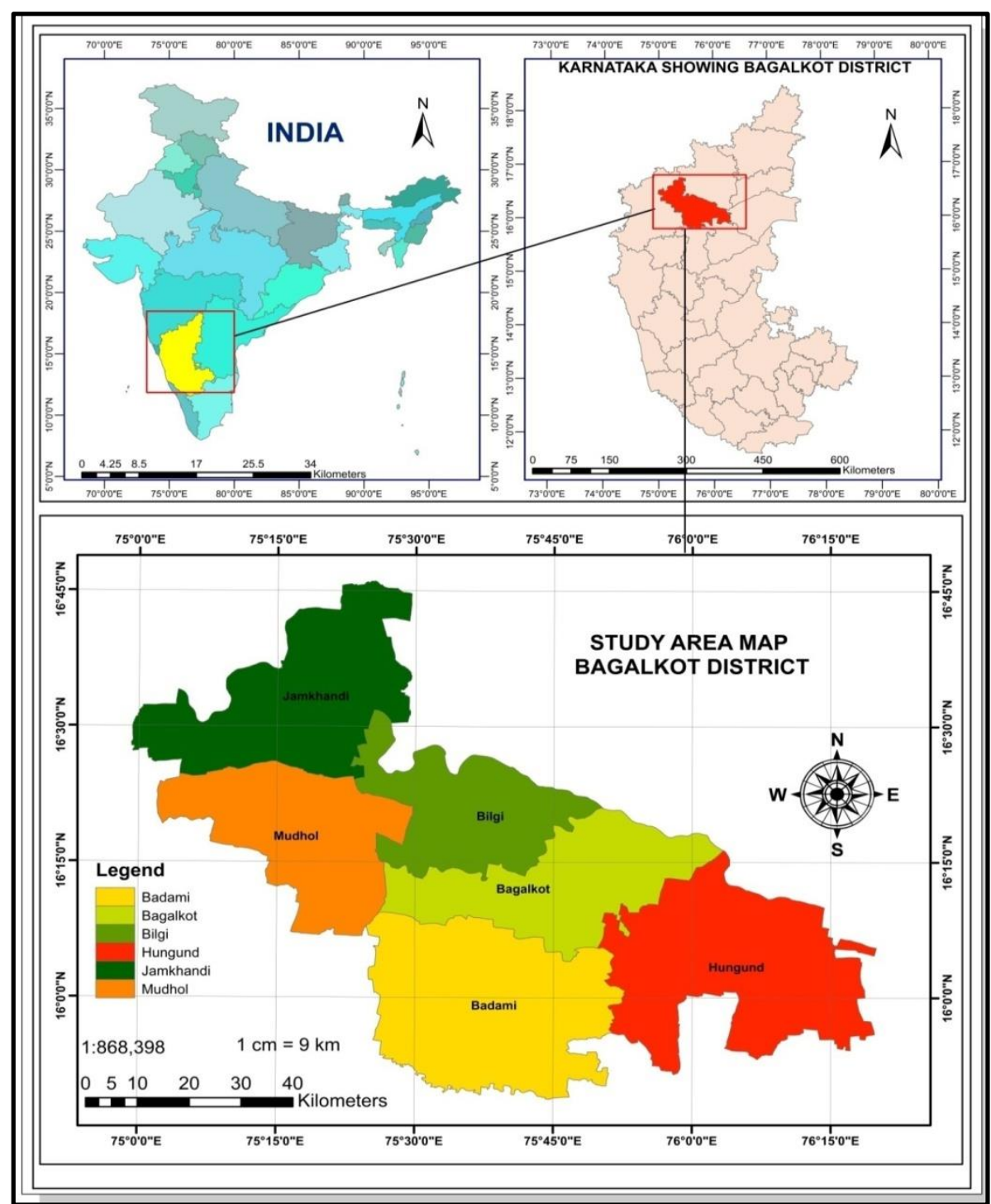

Figure 1: Location Setting of Study Region. 


\section{Location of Study Region}

The study area is in the northern part of the state of Karnataka, and it is part of the northern maiden region. It is situated in the interior of India's Deccan plateau. The Bagalkot district is located between $15^{\circ} 49^{\prime}$ and $16^{\circ} 46^{\prime}$ north latitude and $74^{\circ} 55^{\prime}$ and $76^{\circ} 20^{\prime}$ east longitude. Bijapur district borders the district on the north, part of Belgaum district on the west, Bijapur and Raichur districts on the east, and Koppal and Gadag districts on the south. According to the Government of India's central statistical office, it accounted for around $6575 \mathrm{sq} \mathrm{km}$ of the district's total geographical area.

\section{METHODOLOGY}

Land use and land a cover map is prepared by using the following parameters Google Earth's Satellite Image Landsat / Copernicus dated on $31^{\text {st }}$ December 2016 at the elevation of $610 \mathrm{~m}$, image processing is done using QGIS,

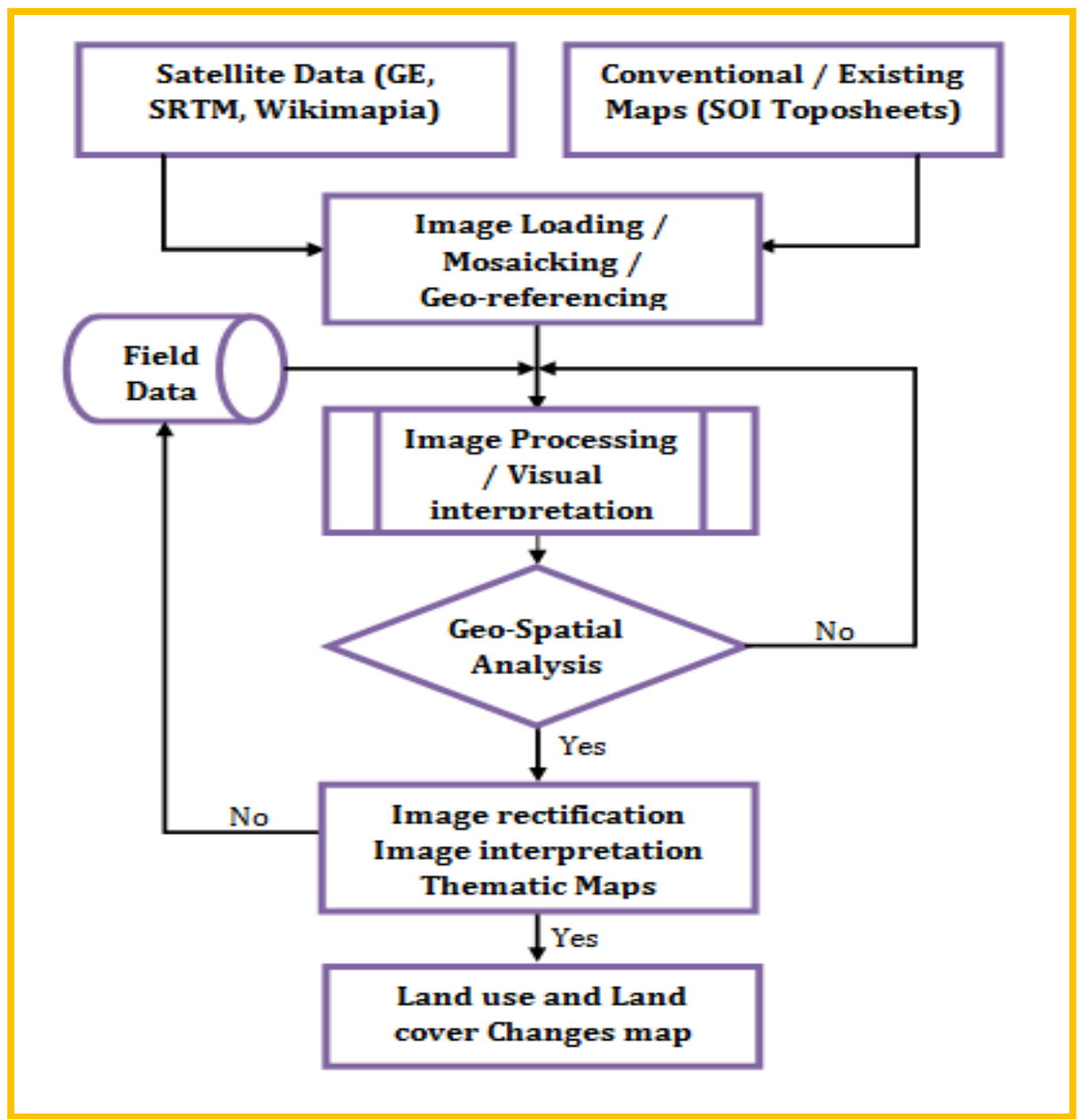

Figure 2: Flow Chart of Methodology.

\section{SIGNIFICANCE FOR THE STUDY}

Bagalkot district is located in the northern section of Karnataka State, in the Deccan Plateau or Bailusime region. The highland portions of Karnataka's Bagalkote district are part of the semi-arid zone, which has sparse and irregular rainfall. These locations in the state have been designated as chronically drought-affected. Famines have struck the region on several occasions in the past, and their frequency has grown during the last five decades. It is widely acknowledged that the 
most efficient strategy to eradicate drought and starvation, as well as to reverse the desertification process, is to increase water supplies to the area. With the introduction of satellite remote sensing and computer-based Geographic Information Systems (GIS). Environmental planners can now obtain the correct overall perspective with the least amount of effort and money invested. With these considerations in mind, the current project will use GIS and remote sensing technologies to supplement and optimise the use of water resources and watershed management programmes, resulting in overall socioeconomic development and poverty alleviation in the study region.

\section{LAND USE LAND COVER}

Land use categorization is the systematic grouping of diverse classes of land on the basis of certain comparable qualities, with the goal of intelligently and effectively identifying and understanding their core utility in meeting people's requirements.

Broadly, the researcher classified 16 different groups mentioned table1 and 2 taking Bagalkot district as a whole into considering out of $6575 \mathrm{sq} \mathrm{km}$ of the geographical area the main bulk of the land area(73.20 percent) is devoted to Agriculture and cropland (75.30 percent) about in 2005-06forest and scrub-covered area is (7.66 percent) in 2015-16(9.57 percent)and about (5.71 percent) agriculture fallow in 2005-06 in 2015-16 (0.32 percent) in 2015-16.The remaining land according to 2015-16. Wetland and waterbodies (5.14 percent).

- Agriculture and cropland: The distribution of arable land in the district is profoundly influenced by terrain conditions. The area under agricultural land is very high due to plain area and which accounts $4913.24 \mathrm{sq}$ $\mathrm{km}(73.20$ percent) in 2005-06 in the last ten years 2015-16,(75.30 percent)has shown increase in the district (2.1 percent) increase recorded. The increase is due to irrigation facility in the district and gentle hill slope area and open country an undulating plain.

- Forest area: The second dominant land use in the district which is forest area out of $504.04 \mathrm{sq} \mathrm{km} \mathrm{(7.66} \mathrm{percent)} \mathrm{in}$ 2005-06 and slight increase in the forest $629.86 \mathrm{sq} \mathrm{km} \mathrm{(9.57} \mathrm{percent)} \mathrm{According} \mathrm{to} \mathrm{the} \mathrm{state} \mathrm{average} \mathrm{and} \mathrm{the}$ national average forest area is less than the district.

- Wetlands waterbodies and ReservoirLake: Wetlands and water bodies dominated the land in study area $269.68 \mathrm{sq}$ $\mathrm{km}$ (4.10 percent) in 2005-06. In 2015-16 occupied 338.19 sq.km (5.14 percent)from last one decade increased (1.04 percent).

- Agriculture and fallow: The fallow land reveals the traditional nature of arable land. There are many reasons to keep fallow land in the district. such as excessive soil erosion silting, salinity and flooding. A total of $375.8 \mathrm{sq} . \mathrm{km}$ (5.71 percent) in 2005-06 and in 2015-16 fallow land is 21.14 (0.32 percent)that is tremendously decreased (-5.39 percent)

- Built-up Area: Built-up in the study area is 2005-06 square km (0.55 percent) in 2015-16 (1.30 percent)within last decade $(0.75$ percent $)$ increased in the built up area. 
Table 1: Land Use Land Cover of Bagalkot District 2005-2006

\begin{tabular}{|c|l|c|c|}
\hline Sl. Number & \multicolumn{1}{|c|}{ Land Use } & Area in Square Kms & Percentage \\
\hline 1 & Builtup,Urban & 36.5 & 0.55 \\
\hline 2 & Builtup,Mining & 13.79 & 0.21 \\
\hline 3 & Agriculture,Plantation & 9.55 & 0.14 \\
\hline 4 & Forest,Deciduous & 79.56 & 1.21 \\
\hline 5 & Forest,Scrub Forest & 504.14 & 7.66 \\
\hline 6 & Barren/unculturable/ Wastelands, Gullied/Ravinous Land & 1.04 & 0.015 \\
\hline 7 & Barren/unculturable/ Wastelands, Barren rocky & 117.53 & 1.78 \\
\hline 8 & Wetlands/Water Bodies, River/Stream/canals & 90.43 & 1.37 \\
\hline 9 & Builtup,Rural & 63.8 & 0.97 \\
\hline 10 & Agriculture,Cropland & 4813.24 & 73.20 \\
\hline 11 & Agriculture,Fallow & 375.8 & 5.71 \\
\hline 12 & Forest,Forest Plantation & 24.72 & 0.37 \\
\hline 13 & Barren/unculturable/ Wastelands, Salt Affected land & 2.09 & 0.03 \\
\hline 14 & Barren/unculturable/ Wastelands, Scrub land & 172.61 & 2.62 \\
\hline 15 & Wetlands/Water Bodies, Inland Wetland & 0.52 & 0.007 \\
\hline 16 & Wetlands/Water Bodies, Reservoir/Lakes/Ponds & 269.68 & 4.10 \\
\hline & & 6575.00 & 100 \\
\hline
\end{tabular}

Table 2: Land Use Land Land Cover of Baglkot District 2015-16

\begin{tabular}{|c|l|c|c|}
\hline SI. Number & \multicolumn{1}{|c|}{ Land Use } & Area in Square Kms & Percentage \\
\hline 1 & Builtup,Urban & 86.04 & 1.30 \\
\hline 2 & Builtup,Mining & 18.51 & 0.28 \\
\hline 3 & Agriculture,Plantation & 7.34 & 0.11 \\
\hline 4 & Forest,Deciduous & 39.06 & 0.59 \\
\hline 5 & Forest,Scrub Forest & 629.86 & 9.57 \\
\hline 6 & Barren/unculturable/ Wastelands, Gullied/Ravinous Land & 2.59 & 0.04 \\
\hline 7 & Barren/unculturable/ Wastelands, Barren rocky & 84.5 & 1.28 \\
\hline 8 & Wetlands/Water Bodies, River/Stream/canals & 81.24 & 1.23 \\
\hline 9 & Builtup,Rural & 93.61 & 1.42 \\
\hline 10 & Agriculture,Cropland & 4951.46 & 75.30 \\
\hline 11 & Agriculture,Fallow & 21.14 & 0.32 \\
\hline 12 & Forest,Forest Plantation & 13.77 & 0.20 \\
\hline 13 & Barren/unculturable/ Wastelands, Salt Affected land & 15.84 & 0.24 \\
\hline 14 & Barren/unculturable/ Wastelands, Scrub land & 185.89 & 2.82 \\
\hline 15 & Wetlands/Water Bodies, CoastalWetland & 5.96 & 0.09 \\
\hline 16 & Wetlands/Water Bodies, Reservoir/Lakes/Ponds & 338.19 & 5.14 \\
\hline & $\quad$ Total land & $\mathbf{6 5 7 5}$ & $\mathbf{1 0 0}$ \\
\hline
\end{tabular}


Table 3: Volume of Change Land Use 2005-06 to 2015-16

\begin{tabular}{|c|l|c|c|c|}
\hline SI. No. & \multicolumn{1}{|c|}{ Land Use Classification } & $\begin{array}{c}\text { Land Use 2015- } \\
\mathbf{1 6}\end{array}$ & $\begin{array}{c}\text { Land Use 2005- } \\
\text { 06 }\end{array}$ & $\begin{array}{c}\text { Volume of } \\
\text { Change }\end{array}$ \\
\hline 1 & Builtup,Urban & 1.30 & 0.55 & 0.75 \\
\hline 2 & Builtup,Mining & 0.28 & 0.21 & 0.07 \\
\hline 3 & Agriculture,Plantation & 0.11 & 0.14 & -0.03 \\
\hline 4 & Forest,Deciduous & 0.59 & 1.21 & -0.62 \\
\hline 5 & Forest,Scrub Forest & 9.57 & 7.66 & 1.91 \\
\hline 6 & $\begin{array}{l}\text { Barren/unculturable/ Wastelands, } \\
\text { Gullied/Ravinous Land }\end{array}$ & 0.04 & 0.015 & 0.025 \\
\hline 7 & $\begin{array}{l}\text { Barren/unculturable/ Wastelands, Barren } \\
\text { rocky }\end{array}$ & 1.28 & 1.78 & -0.5 \\
\hline 8 & Wetlands/Water Bodies, River/Stream/canals & 1.23 & 1.37 & -0.14 \\
\hline 9 & Builtup,Rural & 1.42 & 0.97 & 0.45 \\
\hline 10 & Agriculture,Cropland & 75.30 & 73.20 & 2.1 \\
\hline 11 & Agriculture,Fallow & 0.32 & 5.71 & -5.39 \\
\hline 12 & Forest,Forest Plantation & 0.20 & 0.37 & -0.17 \\
\hline 13 & $\begin{array}{l}\text { Barren/unculturable/ Wastelands, Salt } \\
\text { Affected land }\end{array}$ & 0.24 & 0.03 & 0.21 \\
\hline 14 & Barren/unculturable/ Wastelands, Scrub land & 2.82 & 2.62 & 0.2 \\
\hline 15 & Wetlands/Water Bodies, CoastalWetland & 0.09 & 0.007 & 0.083 \\
\hline 16 & $\begin{array}{l}\text { Wetlands/Water Bodies, } \\
\text { Reservoir/Lakes/Ponds }\end{array}$ & 5.14 & 4.10 & 1.04 \\
\hline
\end{tabular}

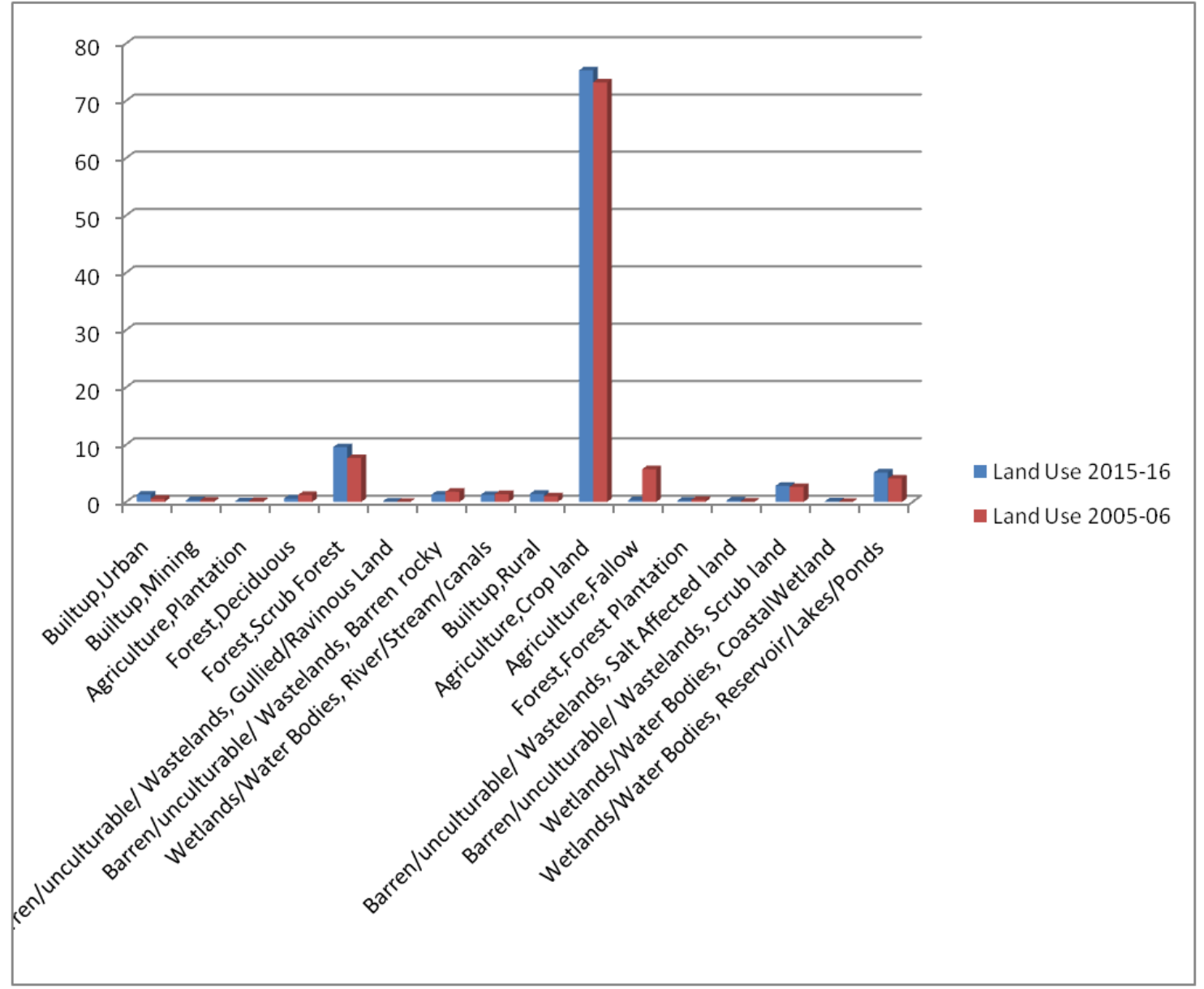

Figure 3: Volume of Change Land use Land Cover. 


\section{CONCLUSIONS}

A region's land use/land cover (LULC) pattern in time and space is the result of natural and socioeconomic variables, as well as man's use of them. Land use and land cover research has become a key component of contemporary policies for sustainable natural resource management and monitoring environmental changes in the region. A region's land use/land cover (LULC) pattern in time and space is the result of natural and socioeconomic variables, as well as man's usage of them after construction. Upper Krishna Project in Bagalkot district change in the land use land cover in Bagalkot District, Karnataka, Hence, land use manipulation by human beings is widespread and has become a serious threat to watershed services including streamflow regulation, soil erosion control and low-flow augmentation at both micro-and macro-level catchments. Broadly, the researcher classified 16 different groups mentioned table1 and 2 taking Bagalkot district as a whole into considering out of $6575 \mathrm{sq} \mathrm{km}$ of the geographical area the main bulk of the land area(73.20 percent) is devoted Agriculture and cropland (75.30 percent) about in 2005-06forest and scrub-covered area is (7.66 percent) in 2015-16(9.57 percent)and about (5.71 percent) agriculture fallow in 2005-06 in 2015-16 (0.32 percent) in 2015-16. The remaining land according to $2015-16$. Wetland and waterbodies (5.14 percent).

\section{REFERENCES}

1. Amba Shetty, Lakshman Nandagir, Sangeeta Thokchom. and Rajesh, M. V S., 2005. Land use - Land cover mapping using satellite data for a forested watershed, Udupi district, Karnataka state. India Journal of the Indian Society of Remote Sensing. 33 (2), 233-238.

2. Anita. K., Prakash. I. V., Muralikrishna, Mishra, P. K. and Chalam, R. V. R. K., 2007. Deciding alternative land use options in a watershed using gis. Journal of Irrigation and Drainage Engineering, (Asce). 133, 62-174.

3. Arabinda Sharma, Kamlesh, N. Tiwari, P. And Bhadoria B. S, 2011. Effect of land use land cover change on soil erosion potential in an agricultural watershed. Journal of Environ Monit Assess (springer). 173, 789-801.

4. Bisht. B. S. And Kothyari, B. P., 2002. Land-cover change analysis of Garur Ganga watershed using gis/remote sensing technique. Journal of the Indian Society of Remote Sensing. 29 (3), 138-141.

5. Chakraborty, M., 2009. An approach towards urban form analysis and land-use classification: a case of Ahmedabad, India." M.sc. Dissertation, international institute for geo-information science and earth observation. Enschede, the Netherlands.

6. Foody, G., 1992. On the compensation for chance agreement in image classification accuracy assessment. Photogrammetric Engineering \& remote sensing. 58 (10), 1459-1460.

7. Gautam, N. C. and Narayanan, E. R., 1983. Satellite remote sensing techniques for natural resources survey. L R Singh, Savindra Singh, r c Tiwari and r p Srivastava, (eds:) Environmental Management, Allahabad, pp. 177-181.

8. Griffith, J., Martinko, E., Whistler, J., and Price, K., 2002. Interrelationships among landscapes, ndvi, and stream water quality in the u.s. Central plains. Journal f Ecological Applications. 12, 1702-1718.

9. Jayakumar, S. and Arockiasamy, D. I., 2003. Land use/land cover mapping and change detection in part of eastern ghats of Tamil Nadu using remote sensing and gis. Journal of The Indian Society of Remote Sensing. 31(4), 252-260

10. Jha, C. S, Dutta, C. B. and Bhawa, K. S., 2000.Deforestation and land-use changes in western ghats, India. Current Science. 792, 231-243.

11. Jones, V.T., Matthews, M.D., and Richers, D., 2000. Light hydrocarbons in petroleum and natural gas exploration. Handbook 
of exploration geochemistry: geochemical remote sensing of the

12. Kiran Shankar, Bhisma Kumar, And Sing. B. P., 1979. Determination and analysis of variations of soil moisture at various depths by re-ber neutron scattering probe. 45(5), 476-484

13. Krishnaswamy, J., Bonell, M., Venkatesh, B., Purandara, B.K., Lele, S., Kiran, M.C., Reddy, V.B., Badiger, S. and Rakesh, K.N. 2012. The rain runoff response of tropical humid forest ecosystems to use and reforestation in the western ghats of India. J. Hydrology. 472, 216-237.

14. Krishnaswamy, J., Bunyan, M., Mehta, V. K., Jain, N. and Karanth, K. U., 2006 Impact of iron ore mining on suspended sediment response in a tropical catchment in Kudremukh, western ghats, India. For Ecol Manage. 224, 187-198

15. Lakshmanan. C, Pradeep Kishore. V, Viveganandan. S, Krishnakumar. P, Muthusankar. G., 2012. Landuse / land cover dynamics study in Nilgiris district part of western ghats, Tamilnadu. International Journal of Geomatics And Geosciences. 2 (3), 20-29

16. Lallianthanga, R.K., Robert, And Lalchhanhima Sailo, 2013. Land use planning for sustained utilization of resources using remote sensing \& gis techniques: a case study in Mamit district, Mizoram, India. American Journal of Engineering Research (AJER) 02 (11), 216-222

17. Malissa Hubbard, Elizabeth Norment, and Paul Gerlach. 2013. Land use land cover in the western ghats, India. Master of environmental management degree in the Nicholas school of the environment of duke university

18. Nigam, K., 2000. Application of remote sensing and geographical information system for land use / land cover mapping and change detection in the rural-urban fringe area of Enschede city, the Netherlands. International Archives of Photogrammetry and Remote Sensing. Vol. Xxxiii, part b7. Amsterdam 2000.

19. Pandian. M, Rajagopal.N, Sakthivel. G., and Amrutha. D., 2014. Land use and land cover change detection using remote sensing and gis in parts of Coimbatore and Tiruppur districts, Tamil Nadu, India”. International Journal of Remote Sensing \& Geoscience (IJRSG) 3 (1), 2319-3484. 